\title{
Survey of Bacteria in the Farm of Faculty of Agriculture ,Al-Azahr University, Assiut Governorate,Egypt
}

\author{
Said A.M. El-Sayed 1
}

\begin{abstract}
Two hundred and fifteen soil bacteria isolates able to reduce $\mathrm{NO}_{3}^{-}, 210$ produced nitrous oxide $\left(\mathrm{N}_{2} \mathrm{O}\right)$, even only 47 were respiratory denitrifiers . Nitrite or $\mathrm{NH}_{4}^{+}$was the major product of $\mathrm{NO}_{3}^{-}$reduction by the non-denitrifying organisms, but typically about 5 to $10 \%$ and up to $34 \%$ of the $\mathrm{NO}_{3}^{-}$reduced by them was released as $\mathrm{N}_{2} \mathrm{O}$ during a 2week incubation period. Bacillus and Enterobacter were the most commonly observed genera of non-denitrifying $\mathrm{N}_{2} \mathrm{O}$ producers. Fermentative $\mathrm{NO}_{2}^{-}$reduction and $\mathrm{N}_{2} \mathrm{O}$ production by a Bacillus sp. and a Citrobacter sp. were characterized in pure culture studies. Dinitrogen $\left(\mathbf{N}_{2}\right)$ was not produced in detectable quantities by these organisms. When added to autoclaved soil, they accumulated more $\mathrm{N}_{2} \mathrm{O}$ than two denitrifying pseudomonads, since the latter consume and produce $\mathrm{N}_{2} \mathrm{O}$. In tryptic soy broth (TSB), which allows active fermentative growth, $\mathrm{NH}_{4}^{+}$was apparently the major product of $\mathrm{NO}_{3}^{-}$reduction. Added $\mathrm{NH}_{4}^{+}$did not inhibit $\mathrm{N}_{2} \mathrm{O}$ production or apparent reduction to $\mathrm{NH}_{4}^{+}$, indicating that these processes are not essimilatory . The effect added glucose on $\mathrm{N}_{2} \mathrm{O}$ production varied with the organism and media composition. Nitrous oxide production from $\mathrm{NO}_{2}^{-}$by these organisms was shown to be at least partially a biochemical reaction. The $\mathrm{N}_{2} \mathrm{O}$ evolved slowly in bath cultures and mostly after apparent growth ceased. This is apparently a novel mechanism of $\mathrm{N}_{2} \mathrm{O}$ generation which differs significantly from respiratory denitrification .
\end{abstract}

Key words: Nutrient broth (NB), tryptie soy broth (TSB), nitrite reduction, denitrification, dissimilatory ammonium production.

\section{INTRODUCTION}

There is much current interest in soil denitrification, promoted by the need to utilize nitrogen $(\mathrm{N})$ fertilizer more efficiently, and in soil evolution of nitrous oxide $\left(\mathrm{N}_{2} \mathrm{O}\right)$, promoted by the hypothesized role of this gas in the destruction of atmospheric ozone (C.A.S.T,1979; Caskey and Tiedje, 1976; Crutzen and Ehhalt, 1977; Mc Elroy et al., 1977).This has led to reevaluation of the mechanisms and organisms responsible for the production of gaseous $\mathrm{N}$ and the reduction of $\mathrm{N}$ oxides. Recent evidence suggests that $\mathrm{NH}_{4}^{+}$- oxidizing bacteria like Nitrosomonas are important sources of $\mathrm{N}_{2} \mathrm{O}$ (Bremner and Blackmer, 1978; Breitenbeck et al ., 1980), and that production of this gas is not the exclusive province of denitrifying bacteria as previously believed.The term denitrification has been used to refer to any conversion of $\mathrm{NO}_{3}^{-}$or $\mathrm{NO}_{2}^{-}$to $\mathrm{N}$ gas. It is now commonly used by microbiologists; however, to describe only the reduction of $\mathrm{NO}_{3}^{-}$and $\mathrm{NO}_{2}^{-}$to $\mathrm{NO}$, $\mathrm{N}_{2} \mathrm{O}$ or $\mathrm{N}_{2}$ in bacterial respiration, and the term will be used in this sense here. Other known mechanism of $\mathrm{N}_{2} \mathrm{O}$ production include a variety of chemical reactions (Nelson and Bremner, 1970), production by nitrifiers, and by a miscellany of non-denitrifying fungi and bacteria (Yoshida and Alexander, 1970). The nature and relative significance of these various mechanisms are only vaguely understood at present.

Dissimilatory $\mathrm{NO}_{3}^{-}$-reducing bacteria have conventionally been considered to be of two types: (i) respiratory denitrifiers which can reduce $\mathrm{NO}_{3}^{-}$ completely to $\mathrm{N}$ gasses, and (ii) $\mathrm{NO}_{3}^{-}$respires or $\mathrm{NO}_{2}^{-}$ accumulators which are able to respire $\mathrm{NO}_{3}^{-}$only as far as $\mathrm{NO}_{2}^{-}$(Payne, 1973 and EL-Sayed, 2002(a and b)). Though it has been known that at least a few of the latter type of organism growing fermentatively can further dissimilate $\mathrm{NO}_{2}^{-}$to $\mathrm{NH}_{4}^{+}$, the significance of this process has been suggested only in publications (Caskey and Tiedje, 1979; Sorenson, 1978 ; EL-Sayed , 2003 a). These fermentative organisms presumably attain greater ATP yields, by recycling reduced nucleotides via $\mathrm{NO}_{2}^{-}$reduction to $\mathrm{NH}_{4}^{+}$(Cole and Brown, 1980 ; EL-Sayed , 2003 b), from substrate level phosphorylation. In contrast, respiratory denitrifiers reduce $\mathrm{NO}_{2}^{-}$to $\mathrm{N}$ gases and generate ATP by electron transport phosphorylation. Ammonium is the only product of fermentative, dissimilatory $\mathrm{NO}_{2}^{-}$reduction which has been considered in the literature.In earlier work, however, it was noted that $\mathrm{N}_{2} \mathrm{O}$ was evolved from $\mathrm{NO}_{3}^{-}$by a variety of organisms presumed to be nondenitrifying $\mathrm{NO}_{3}^{-}$reduces (Caskey and Tiedje , 1979 ; EL-Sayed , 2013). The objectives of this study were to characterize the mechanism of $\mathrm{N}_{2} \mathrm{O}$ production, examine its significance as a source of $\mathrm{N}_{2} \mathrm{O}$ in soil, and determine the end products of $\mathrm{NO}_{3}^{-}$reduction for a large sample of soil isolates.

\section{MATERIALS AND METHODS}

\section{Isolation of soil $\mathrm{NO}_{3}^{-}$Reducers:-}

Samples of silt loam soil ( mixed mesic Typic ), $\mathrm{pH}$ 7.1 , and $1 \%$ organic matter) and silty clay loam soil (mixed thermic cumulic of $\mathrm{pH} 7.1$ and $1.3 \%$ organic matter) were collected from the surface $(0-15 \mathrm{~cm})$ of

\footnotetext{
${ }^{11}$ Soil and Water Science Dept.,Faculty of Agric. In Assiut, $\mathrm{Al}$-Azhar University

Received December 07,2017, Accepted December 30, 2017
} 
corn fields. These samples were stored at field moisture contents at 2 to $4^{\circ} \mathrm{C}$. In some experiments $20.0 \mathrm{gm}$, soil samples were pre incubated anaerobically for 78 hours prior to isolation of $\mathrm{NO}_{3}^{-}$reducers. Twenty grams of soil were blended for 60 seconds in $190 \mathrm{ml} 0.85 \% \mathrm{Nacl}$ solution with 1 drop of Tween 80 . A tenfold dilution series was prepared in sterile Nacl solution. Dilutions were spread on plates of either tryptic soy or nutrient agar (Difco) with $5 \mathrm{~m} \mathrm{M} \mathrm{KNO}_{3}$. Results for the two media were pooled since no significant differences were observed among the $\mathrm{NO}_{3}^{-}$reducing organisms . Plates were incubated 4 days in anaerobic chamber at room temperature. Isolated colonies were picked at random and in some experiments were further purified by streaking on $\mathrm{NO}_{3}^{-}$nutrient agar and incubating anaerobically. In other experiments, isolated colonies were assayed directly without further purification(ELSayed et al.,2001).

\section{Characterization of $\mathrm{NO}_{3}^{-}$Reducing Isolates}

Isolates were used to inoculate $5 \mathrm{ml}$ of nutrient broth plus $5 \mathrm{~m} \mathrm{M} \mathrm{KNO}_{3}$, contained in Hungate tubes (Bellco). Oxygen was removed from the tubes by evacuating and flushing with $\mathrm{N}_{2}$ gas passed through 0.45- u Gelman filters.

To fervent the reduction of $\mathrm{N}_{2} \mathrm{O}$ to $\mathrm{N}_{2}$, acetylene $\left(\mathrm{C}_{2} \mathrm{H}_{2}\right)$ was injected aseptically to a partial pressure of 8 $\mathrm{KPa}$. In the same experiments, the isolates were also cultured in tubes without $\mathrm{C}_{2} \mathrm{H}_{2}$ or with trypic soy broth (with dextrose) in place of nutrient broth. Nitrous oxide was sampled after through mixing by withdrawing 0.5 $\mathrm{ml}$ from the headspace with a tuberculin syringe. Following gas analysis, cultures were centrifuged, and the clear supernatants were frozen for later $\mathrm{NO}_{3}^{-}$and $\mathrm{NO}_{2}^{-}$determinations(EL-Sayed,2005).

\section{Pure Culture Studies}

Cultures from selected tubes were checked for purity and maintained on $\mathrm{NO}_{3}^{-}$agar (Difco) for further taxonomic or physiological characterization. Gram stain, sporulation, motility, and standard tests for reaction with sugars, litmus milk, citrate, and indole were observed for these isolates to identify them at the genus level.

All pure cultures were grown at $24^{\circ} \mathrm{C}$ with $10 \mathrm{ml}$ of the appropriate media in Hungate tubes. Tubes were inoculated with $0.1 \mathrm{ml}$ of an ( 18 to 24 ), hour culture (early stationary phase) grown anaerobically in $\mathrm{NO}_{3}^{-}$ broth, then immediately evacuated and flushed with $\mathrm{N}_{2}$ gas aseptically. The time course of $\mathrm{NO}_{3}^{-}$reduction and $\mathrm{NO}_{2}^{-}$and $\mathrm{N}_{2} \mathrm{O}$ production during growth in nutrient broth with $5 \mathrm{~m} \mathrm{M} \mathrm{KNO}_{3}$ was determined by periodical analyzing three replicate tubes for $\mathrm{N}_{2} \mathrm{O}$ an absorbance and by sacrificing, at frequent intervals, three additional replicates for $\mathrm{NO}_{3}^{-}$and $\mathrm{NO}_{2}^{-}$analysis. Growth yield responses to $\mathrm{NO}_{3}^{-}$and $\mathrm{NO}_{2}^{-}$were measured gravimetrically after washing cells in distilled water and drying at $85^{\circ} \mathrm{C}$. Filter- sterilized $\mathrm{NO}_{2}^{-}$was added to media after autoclaving, but $\mathrm{NO}_{3}^{-}$was autoclaved with the broth. The effect of $\mathrm{pH}$ on $\mathrm{N}_{2} \mathrm{O}$ production was observed by adding $\mathrm{HC} 1$ or $\mathrm{NaoH}$ to nutrient broth before autoclaving. The $\mathrm{pH}$ of replicate tubes was measured after autoclaving and was either unchanged or increased by only 0.1 unit. The appropriate quantities of $\left(\mathrm{NH}_{4}\right)_{2} \mathrm{SO}_{4}, \mathrm{KNO}_{3}$, or glucose were added to either tryptic soy broth (without dextrose) or nutrient broth to observe the effects of media composition on $\mathrm{N}_{2} \mathrm{O}$ production. To assay for $\mathrm{N}_{2}$ production, tubes were initially flushed with helium and incubated under water to minimize atmospheric contamination.

Resting cell suspensions were prepared from early stationary phase cultures harvested by centrifugation and repeated washing in $50 \mathrm{mM} \mathrm{pH} 7.0$ phosphate buffer plus $200 \mathrm{ug}$. M /L chloramphenicol to inhibit protein synthesis. In separate assays this chloramphenicol concentration was sufficient to totally inhibit growth of the organisms studied. Cell density in the reaction mixture was approximately 2 times the maximum cell density attained in culture. Complete reaction mixtures consisted of $10 \mathrm{ml}$ of $50 \mathrm{~m} M$ phosphate buffer (pH 7.0) , 200 ug M/L chloramphenicol ,2.8 m $M$ glucose, $5 \mathrm{~m} M \mathrm{NaNO}_{2}, \mathrm{~N}_{2}$ atmospheres, and cells in Hungate tubes. Resting cell suspensions were continuously shaken during the 2hour incubation at room temperature. Gas samples were removed periodically by syringe (EL-Soury et al.,2015).

\section{$\mathbf{N}_{2} \mathrm{O}$ production in Inoculated Axenic Soils}

Twenty- gram samples of the soil were autoclaved for 1 hour on 2 consecutive days. Twenty- four hours anaerobic cultures of two $\mathrm{NO}_{2}^{-}$accumulators and two denitrifiers in nitrate broth were harvested and washed in $10 \mathrm{~m} M \mathrm{CaCl}_{2}$ plus $1.7 \mathrm{~m} M \mathrm{KNO}_{3}$. The two denitrifiers had been isolated from soil and characterized in previous studies ( Gamble et al, 1977; and EL-Sayed , 2005 ). Suspensions were diluted in $\mathrm{CaCl}_{2}, \mathrm{KNO}_{3}$ solution to give equal optical densities for all the organisms, and $10 \mathrm{ml}$ was added to $20 \mathrm{~g}$ of autoclaved soil, given approximately $5 \times 10^{8}$ cells/g of soil. Control soils not inoculated received $10 \mathrm{ml}$ of $\mathrm{CaCl}_{2}, \mathrm{KNO}_{3}$ solution with no cells. The flask containing the slurries were made anaerobic and incubated on a rotary shaker $(150 \mathrm{rpm})$ at room temperature. Frequent headspace samples were removed by syringe for $\mathrm{N}_{2} \mathrm{O}$ analysis.

\section{Chemical Analysis}

Nitrous oxide $\left(\mathrm{N}_{2} \mathrm{O}\right)$ was measured with a Varian 3700 gas chromatograph equipped with Porapak Q columns and operated isothermally at $50^{\circ} \mathrm{C}$. Samples 
containing 0.05 to $30 \mathrm{ppm}(\mathrm{v} / \mathrm{v}) \mathrm{N}_{2} \mathrm{O}$ were measured with a ${ }^{63} \mathrm{Ni}$ electron capture detector at $340^{\circ} \mathrm{C}$ with $10 \% \mathrm{CH}_{4}$ in argon carrier gas. Separation between $\mathrm{CO}_{2}$ and $\mathrm{N}_{2} \mathrm{O}$ was sufficient to prevent $\mathrm{CO}_{2}$ interaction with $\mathrm{N}_{2} \mathrm{O}$ response. A four-port in-oven venting value was used to prevent other gases from reaching the detector. Samples with $\mathrm{N}_{2} \mathrm{O}$ concentrations exceeding $30 \mathrm{ppm}$ were measured by thermal conductivity detector with helium as the carrier gas, again using Porapak Q columns at $50^{\circ} \mathrm{C}$. Quantities of $\mathrm{N}_{2} \mathrm{O}$ in solution were calculated using published values of the Bunsen absorption coefficient. Dinitrogen was separated on a molecular sieve 5 Ation column and analyzed by thermal conductivity detector.

The presence of $\mathrm{NO}_{3}^{-}$was determined qualitatively in the characterization of soil isolates by treating a small subsample, about $0.1 \mathrm{ml}$, with 2 drops of $5 \%$ sulfamic acid to remove $\mathrm{NO}_{2}^{-}$, then adding 3 drops of diphenylamine $\mathrm{HCl}$ in concentrated $\mathrm{H}_{2} \mathrm{SO}_{4}$. A strongto- moderate blue color was developed with concentrations greater than about $0.5 \mathrm{~m} M \mathrm{NO}_{3}^{-}$, Quantitative $\mathrm{NO}_{3}^{-}$determinations were made with an Orion $\mathrm{NO}_{3}^{-}$electrode after removing $\mathrm{NO}_{2}^{-}$with sulfamic acid, then mixing the sample with an equal volume of $0.052 \mathrm{M} \mathrm{AL}_{2}\left(\mathrm{SO}_{4}\right)_{3}$. The validity of this technique was verified by analysis of $\mathrm{NO}_{3}^{-}$an $\mathrm{NO}_{2}^{-}$. Nitrite was measured by autoanalyzer using the reaction with $\mathrm{N}-1$ naphthyleth-ylenediamine dihydrochloride and

Table 1. Characterization of soil isolates with regard to products of $\mathrm{NO}_{3}^{-}$reduction after a 2- week incubation in anaerobic nutrient broth (NB) or tryptic soy broth (TSB) with $5 \mathrm{~m} \mathrm{M} \mathrm{KNO}$ and $8 \mathrm{~K} \mathrm{~Pa} \mathrm{C}_{2} \mathrm{H}_{2}$ added

\begin{tabular}{|c|c|c|c|c|c|}
\hline \multirow{2}{*}{$\begin{array}{c}\text { Soil treatment and type } \\
\text { of isolate }\end{array}$} & \multirow{2}{*}{\multicolumn{2}{|c|}{$\begin{array}{l}\text { Number Number producing } \\
\text { of isolates } \mathrm{N}_{2} \mathrm{O}\end{array}$}} & \multirow{2}{*}{$\begin{array}{l}\text { Number which } \\
\text { depleted } \mathrm{NO}_{3}^{-} \\
\text {and } \mathrm{NO}_{2}^{-}\end{array}$} & \multicolumn{2}{|c|}{$\%$ Recovery of added $\mathrm{NO}_{3}^{-}$-as $\mathrm{N}$} \\
\hline & & & & $\mathbf{N}_{2} \mathrm{O}$ & $\mathrm{NO}_{2}^{-}$ \\
\hline \multicolumn{6}{|l|}{ no incubation:- } \\
\hline $\mathrm{NO}_{2}^{-}$accumulators & 59 & 59 & $(49)^{+}$ & 8.8 & 87.8 \\
\hline Presumptive $\mathrm{NH}_{4}^{+}$producers. & 13 & 13 & $8(10)$ & 16.2 & 15.5 \\
\hline Denitrifiers. & 19 & 19 & $18(17)$ & 79.9 & 3.6 \\
\hline $\begin{array}{l}\text { Poor growth or in active } \mathrm{NO}^{-} \\
{ }_{3} \text { reduction. }\end{array}$ & 13 & nd \# & $1(1)$ & nd \# & nd \# \\
\hline \multicolumn{6}{|l|}{ Anaerobic incubation:- } \\
\hline $\mathrm{NO}_{2}^{-}$accumulators. & 61 & 60 & 1 & 8.1 & 85.2 \\
\hline Presumptive $\mathrm{NH}_{4}^{+}$producers. & 2 & 2 & 1 & 12.4 & 37.1 \\
\hline Denitrifiers. & 17 & 17 & 17 & 89.4 & 0.9 \\
\hline $\begin{array}{l}\text { Poor growth, inactive } \mathrm{NO}_{3}^{-} \\
\text {reduction. }\end{array}$ & 74 & nd \# & 1 & nd \# & nd \# \\
\hline soil, no pre incubation:- & & & & & \\
\hline $\mathrm{NO}_{2}^{-}$accumulators. & 38 & 34 & 1 & 11.3 & 82.7 \\
\hline Presumptive $\mathrm{NH}_{4}^{+}$producers & 1 & 1 & 1 & 1 & 1 \\
\hline Denitrifiers. & 13 & 13 & 13 & 89.9 & 1 \\
\hline $\begin{array}{l}\text { Poor growth or inactive } \mathrm{NO}^{-} \\
\text {reduction. }\end{array}$ & 52 & nd \# & 1 & nd \# & nd \# \\
\hline
\end{tabular}

(+) Number which completely reduced $\mathrm{NO}_{3}^{-}$and $\mathrm{NO}_{2}^{-}$in TSB with dextrose given in parenthese; all other results are for incubation in NB.

$(++)$ nd $=$ not determined. sulfanilamide (Lowe and Hamilton, 1967 ; and ELSayed , 2004).

\section{RERSULTS AND DISCUSSION}

\section{Isolation and classification of soil $\mathrm{NO}_{3}^{-}$reducers:-}

Soil isolates classified into four distinct categories with regard to the products of $\mathrm{NO}_{3}^{-}$- reduction (Table $\mathrm{NO}_{3}^{-}-\mathrm{N}$ added in nutrient broth (N B) was recovered as $\mathrm{NO}_{2}^{-}$after 2 weeks and called $\mathrm{NO}_{2}^{-}$accumulators. Those for which $<50 \%$ of the $\mathrm{NO}_{3}^{-} \mathrm{N}$ in nutrient broth was recovered as $\mathrm{N}_{2} \mathrm{O}$ plus $\mathrm{NO}_{2}^{-}$, called $\mathrm{NH}_{4}^{+}$producers, though $\mathrm{NH}_{4}^{+}$accumulation and was not directly measured.Those organisms which reduced $>50 \%$

(usually 75 to $100 \%$ ) of the $\mathrm{NO}_{3}^{-}$to $\mathrm{N}_{2} \mathrm{O}$ in nutrient broth with $8 \mathrm{KP}_{\mathrm{a}} \mathrm{C}_{2} \mathrm{H}_{2}$, presumed to be respiratory denitrifiers. Those organisms which did not reduce $\mathrm{NO}_{3}^{-}$ or which grew too slowly to reliably determine the products of $\mathrm{NO}_{3}^{-}$reduction during a 2- week incubation ( Abdel-Aziz et al , 2003 ; Christopher et al.,2017).

Table (1) gives average recoveries of $\mathrm{N}_{2} \mathrm{O}$ and $\mathrm{NO}_{2}^{-}$ for the various categories. These indicate that recovery of $\mathrm{N}$ was good (except for the $\mathrm{NH}^{+}{ }_{4}$ producers) and that the categories are distinctly different with regard to end products. Summing the results for all soils, there were $155 \mathrm{NO}_{2}^{-}$-accumulating isolates, 46 denitrifiers, 13 $\mathrm{NH}^{+}$producers, and 136 inactive isolates. 1). Those for which $>50 \%$ ( usually 75 to $100 \%$ ) of the 
Anaerobic preincubation of soil did not appear to have a large effect on the results, but the survey is too limited to be conclusive on this point.

A most significant observation is that 150 of 155 $\mathrm{NO}_{2}^{-}$accumulators and all of the presumptive $\mathrm{NH}_{4}^{+}$ producers evolved significant quantities of $\mathrm{N}_{2} \mathrm{O}$, though the gaseous products were always less than the apparent ionic products $\left(\mathrm{NO}_{2}^{-}\right.$and $\left.\mathrm{NH}_{4}^{+}\right)$( EL-Sayed , 1999 ; Faith et al ., 2017). From 2 to $24 \%$ ( mean 9.0\%) of the $\mathrm{NO}_{3}^{-}-\mathrm{N}$ added was converted to $\mathrm{N}_{2} \mathrm{O}$ by isolates in the $\mathrm{NO}_{2-}^{-}$accumulating category ( EL-Sayed , 2013) . Nitrous oxide production by $\mathrm{NO}_{2^{-}}^{-}$accumulating isolates from the soil with no anaerobic soil incubation was measured in $\mathrm{NB}$ with $\mathrm{C}_{2} \mathrm{H}_{2}$, average $8.7 \% \mathrm{~N}_{2} \mathrm{O}$; in NB without $\mathrm{C}_{2} \mathrm{H}_{2}, 6.9 \% \mathrm{~N}_{2} \mathrm{O}$; and in tryptic soy broth with dextrose (T S B) with $\mathrm{C}_{2} \mathrm{H}_{2}, 6.3 \% \mathrm{~N}_{2} \mathrm{O}$.On the average, $\mathrm{C}_{2} \mathrm{H}_{2}$ and $\mathrm{T} \mathrm{S} \mathrm{B} \mathrm{had} \mathrm{minimal} \mathrm{effects} \mathrm{on} \mathrm{N}_{2} \mathrm{O}$ production through media composition by individual organisms as shown below.It is interesting that most of the organisms which accumulated $\mathrm{NO}_{2}^{-}$in $\mathrm{NB}$ apparently produced $\mathrm{NH}_{4}^{+}$in TSB; 48 of 58 isolates completely removed

$\mathrm{NO}_{3}^{-}$, and $\mathrm{NO}_{2}^{-}$from TSB, but no one of them did so in NB.

Table (2) indicates that these categories of $\mathrm{NO}_{3}^{-}$ reducers are taxonomically as well as functionally different. Pseudomonas, Flavobacterium, and Alcaligenes were the only denitrifying genera observed genera. This is in accord once with work by Gamble $e t$. al. (1977) and (EL-Sayed, 2013) whom found that are these three genera numerically dominant in a largeScale Survey of many soils. One $\mathrm{NO}_{2}^{-}$accumulator was also classified as a Flavobacterium, but Bacillus and Enterobacter were more frequently encountered, with one Citrobacter isolate.

\section{Pure Culture Characterization Fermentative $\mathrm{N}_{\mathbf{2}} \mathrm{O}$ producers}

There is an attempt to determine whether or not $\mathrm{N}_{2}$ was evolved by that two $\mathrm{N}_{2} \mathrm{O}^{-}$producing, $\mathrm{NO}_{2}$ accumulators, (Bacillus sp. B37 and Citrobacter sp.

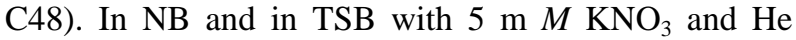
atmosphere, no $\mathrm{N}_{2}$ was detected after 14 days of incubation. All of the $\mathrm{NO}_{3}^{-}$and $\mathrm{NO}_{2}^{-}$was reduced in $\mathrm{TSB}$, and all of the $\mathrm{NO}_{3}^{-}$was reduced in $\mathrm{NB}$, during this time. The $\mathrm{N}_{2}$ could have reliable detection of $\mathrm{N}_{2}$, in this experiment only if $1 \%$ or more of the $\mathrm{N}$ added were released in this from. This can be due to slight atmospheric contamination during syringe sampling and injection. In some of these sampled, very small peaks with retention time corresponding to nitric oxide (NO) were observed. It was apparent that $\mathrm{NO}$ was not a major end product of $\mathrm{NO}_{3}^{-}$reduction, and further work is needed to verify NO produced by these organisms (ELSayed,2005 ; and EL-Sayed $1995 \mathrm{a}$ and b).

The inability of these isolates to produce $\mathrm{N}_{2}$ is further indicated by the observation that $\mathrm{C}_{2} \mathrm{H}_{2}$ did not increase $\mathrm{N}_{2} \mathrm{O}$ accumulation (Table 3) ( EL-Sayed \& Abo-ELwafa, 2001 ; Khalafalla and Hamed , 2015 ). Reduction of $\mathrm{N}_{2} \mathrm{O}$ to $\mathrm{N}_{2}$ is inhibited by $\mathrm{C}_{2} \mathrm{H}_{2}$. It appeared, in fact, that $\mathrm{C}_{2} \mathrm{H}_{2}$ slightly inhibited $\mathrm{N}_{2} \mathrm{O}$ production. The effect of $\mathrm{C}_{2} \mathrm{H}_{2}$ shown in Table (3) was not statistically significant in some cases, but when this experiment was repeated with C48 in NB and in TSB,

\section{Table 2. Taxonomic characterization of selected $\mathrm{NO}_{3}^{-}$reducing soil isolates}

\begin{tabular}{ccc}
\hline Type & Genus & Number of isolates \\
\hline Denitrifiers. & Pseudomonas & 7 \\
& Flavobacterium & 4 \\
$\mathrm{NO}_{2}^{-}$accumulators & Alcaligenes & 3 \\
& Bacillus & 10 \\
& Enterobacter & 4 \\
& Flavobacterium & 2 \\
& Citrobacter & 2 \\
\hline
\end{tabular}

Table 3. Nitrous oxide production by Bacillus sp (B37) and citrobacter sp. (C48) with and without $8 \mathrm{KPa}$ acetylene $^{+}$

\begin{tabular}{ccccc}
\hline Isolate & $\mathbf{C}_{\mathbf{2}} \mathbf{H}_{2}$ & \multicolumn{3}{c}{ Percent $\mathbf{N O}_{3}^{-}$-N converted to $\mathbf{N}_{\mathbf{2}} \mathbf{O}$} \\
\cline { 2 - 5 } & & Day 2 & Day 6 & Day 13 \\
\hline B 37 & - & 2.53 & 3.45 & 4.76 \\
B 37 & + & $1.75++$ & $2.90 \mathrm{n} . \mathrm{s}$ & $4.20 \mathrm{n} . \mathrm{s}$ \\
C 48 & - & 0.41 & 1.04 & 1.18 \\
C 48 & + & $0.40 \mathrm{n} . \mathrm{s}$ & $0.81++$ & $0.92 \mathrm{n} . \mathrm{s}$ \\
\hline
\end{tabular}

+ Anaerobic incubaition in nutrient broth with $9.8 \mathrm{mM} \mathrm{KNO}_{3}^{-}$.

++ Comparisons followed by ++ are significantly different at 0.95 level by two-tailed T-test. N.s. $=$ No significant differences. Values are means of two replicates. 
Table 4. Effect of media composition on products of $\mathrm{NO}_{3}^{-}$reduction by Bacillus sp. (B37) and Citrobacter sp. (C48), measured after 14 days of anaerobic incubation

\begin{tabular}{|c|c|c|c|c|c|c|}
\hline \multirow{2}{*}{ Isolate } & \multirow{2}{*}{ Media } & \multirow{2}{*}{$\begin{array}{c}\text { Added } \\
\text { glucose } \mathbf{g}^{*} \\
\text { liter }^{-1}\end{array}$} & \multirow{2}{*}{$\begin{array}{c}\text { Added } \\
\left(\mathrm{NH}_{4}\right)_{2} \\
\text { SO }_{4} \mathrm{~g}^{*} \text { liter }^{-1}\end{array}$} & \multicolumn{3}{|c|}{$\%$ of $\mathrm{NO}_{3}^{-}-\mathrm{N}$ added converted to $(1 / \mathrm{v})$} \\
\hline & & & & $\mathrm{N}_{2} \mathrm{O}$ & $\mathrm{NO}_{2}^{-}$ & $\left(\mathrm{NH}_{4}^{+}\right)++$ \\
\hline \multirow[t]{10}{*}{ (C 48) } & NB & 1 & 1 & 1.4 & 90.5 & 8.4 \\
\hline & NB & 1 & 0.48 & 1.3 & 89.7 & 9.3 \\
\hline & NB & 0.6 & 1 & 7.0 & 53.0 & 40.3 \\
\hline & NB & 0.6 & 0.48 & 12.5 & 41.5 & 46.3 \\
\hline & NB & 2.6 & 1 & 6.9 & 50.1 & 43.03 \\
\hline & NB & 2.6 & 0.48 & 11.7 & 40.5 & 48.1 \\
\hline & TSBND & 1 & 1 & 11.7 & 6.7 & 81.9 \\
\hline & TSBND & 1 & 0.48 & 12.1 & 5.3 & 82.9 \\
\hline & TSBND & 2.6 & 1 & 3.0 & 1 & 97.2 \\
\hline & TSBND & 2.6 & 0.48 & 3.0 & 1 & 97.2 \\
\hline \multirow{10}{*}{ B37 } & NB & 1 & 1 & 9.7 & 70.0 & 21.5 \\
\hline & NB & 1 & 0.48 & 6.6 & 79.7 & 14.0 \\
\hline & NB & 0.6 & 1 & 7.2 & 71.5 & 21.6 \\
\hline & NB & 0.6 & 0.48 & 9.1 & 71.5 & 19.7 \\
\hline & NB & 2.6 & 1 & 5.8 & 68.7 & 26.8 \\
\hline & NB & 2.6 & 0.48 & 7.4 & 68.2 & 24.7 \\
\hline & TSBND & 1 & 1 & 3.5 & 0 & 96.7 \\
\hline & TSBND & 1 & 0.48 & 3.9 & 0 & 96.3 \\
\hline & TSBND & 2.6 & 1 & 1.3 & 0 & 98.9 \\
\hline & TSBND & 2.6 & 0.47 & 1.3 & 0 & 98.9 \\
\hline
\end{tabular}

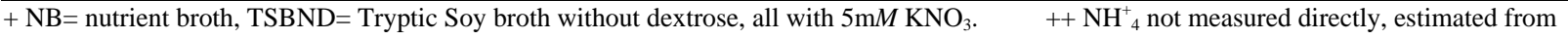
$\left[\mathrm{NO}_{3}^{-}-\left(\mathrm{N}_{2} \mathrm{O}+\mathrm{NO}_{2}^{-}\right)\right]$.

All observation means of three replicats.

consistent inhibition, averaging $18 \%$, was observed. The extent of inhibition was not related to $\mathrm{C}_{2} \mathrm{H}_{2}$ concentration in the range of 2 to $32 \mathrm{KPa}$.

The effects of media composition on the products of $\mathrm{NO}_{3}^{-}$reduction by $\mathrm{C} 48$ and $\mathrm{B} 37$ are shown in Table (4). Nitrous oxide was produced under all conditions, but was never the major product (EL-Sayed , 2002 (a and b) ;and Rajesh et al ., 2017). In complex media it is not feasible to measure directly $\mathrm{NH}_{4}^{+}$production from $\mathrm{NO}^{-}$ 3 without an ${ }^{15} \mathrm{~N}$ label. This is due to confounding reactions such as amino acid degradation and $\mathrm{NH}_{4}^{+}$ assimilon.

Since, showing that $\mathrm{N}_{2}$ and $\mathrm{NO}$ are not major products, it is highly probable that the unaccounted - for $\mathrm{N}$ was reduced to $\mathrm{NH}_{4}^{+}$, the observation of $\mathrm{NH}^{+}{ }_{4}$ accumulation by these organisms, which relates well to the results in Table (4). In parallel experiments. Therefore, $\mathrm{NH}_{4}^{+}$production was estimated by subtracting the $\mathrm{NO}_{2-}^{-} \mathrm{N}$ and $\mathrm{N}_{2} \mathrm{O}-\mathrm{N}$ from the $\mathrm{NO}_{3}^{-}{ }^{-} \mathrm{N}$ added (no $\mathrm{NO}_{3}^{-}$remained after 13 days). The addition of $\mathrm{NH}_{4}^{+}$did not have a significant effect on the apparent reduction of $\mathrm{NO}_{2}^{-} \mathrm{A} \mathrm{NH}_{4}^{+}$, causing slight increases in $\mathrm{NH}_{4}^{+}$production with $\mathrm{C} 48$ and slight decreases with B37. Ammonium additions did not consistently alter

$\mathrm{N}_{2} \mathrm{O}$ production either. Assimilatory $\mathrm{N}_{2} \mathrm{O}^{-}$reduction is repressed by $\mathrm{NH}_{4}^{+}$(Payne, 1973 ; EL-Sayed , 2013). It is concluded that reduction of $\mathrm{NO}_{2}^{-}$to $\mathrm{NH}_{4}^{+}$and $\mathrm{N}_{2} \mathrm{O}$ by these organisms is dissimilatory (EL-Sayed,2016).

Glucose additions consistently increased the apparent production of $\mathrm{NH}_{4}^{+}$Table (4), presumably by permitting more fermentative growth. In $\mathrm{NB}, \mathrm{NO}_{2}^{-}$was the major product; but in TSB, with or without dextrose, $\mathrm{NH}_{4}^{+}$was. This is consistent with results presented in Table (1).Glucose did not affect $\mathrm{N}_{2} \mathrm{O}$ production consistently. Citrobacter $\mathrm{C} 48$ in $\mathrm{NB}$ produced significantly more $\mathrm{N}_{2} \mathrm{O}$ when glucose was added, but B37 in NB tended to produce slightly but not significantly less. Glucose significantly depressed $\mathrm{N}_{2} \mathrm{O}$ evolution by both organisms in TSB.

Nitrous oxide production and growth of $\mathrm{C} 48$ and B37 with various $\mathrm{NO}_{3}^{-}$concentrations are shown in Table (5). Growth responses in NB were observed up to $15 \mathrm{~m} \mathrm{MNO}_{3}^{-}$, AT $5 \mathrm{~m} \mathrm{MNO}_{3}^{-}$in NB, therefore, the supply of electron acceptor is growth- limiting. Under these conditions, rapid reduction of both $\mathrm{NO}_{3}^{-}$and $\mathrm{NO}_{2}^{-}$ would be expected for respiratory denitrifires, yet $\mathrm{C} 48$ and B37 do not rapidly reduce $\mathrm{NO}_{2}^{-}$as shown in Fig ,(1) and in Table (4). 


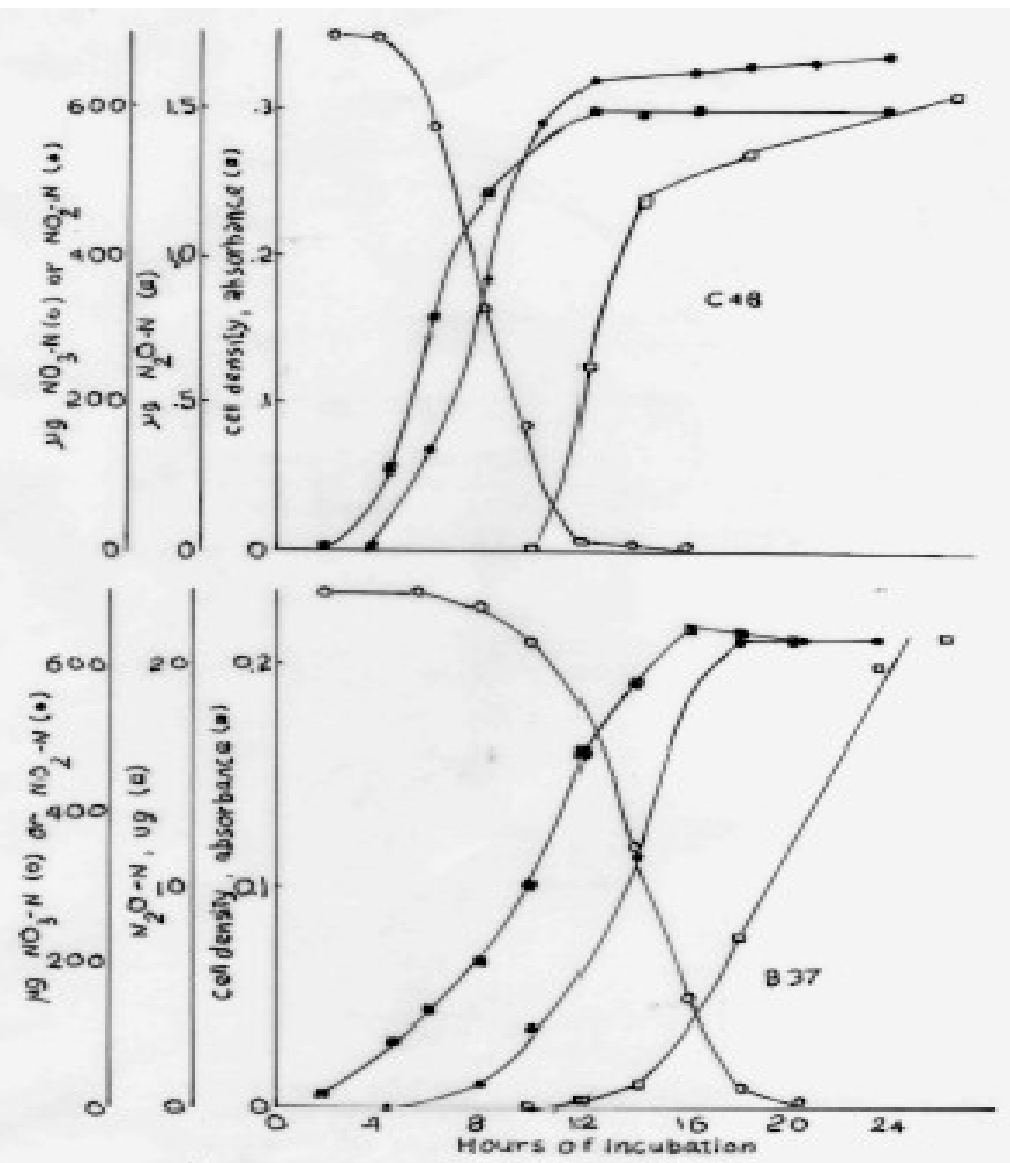

Fig. 1. reduction of $\mathrm{NO}_{3}^{-}(0)$, production of $\mathrm{NO}_{2}^{-}(\bullet)$ and $\mathrm{N}_{2} \mathrm{O}(\square)$, and increase in turbidity ( $\bullet$ ) by cultures of Bacillus sp. B37 (1B) and Citrobacter sp. C48 (1A in anaerobic nutrient broth initially containing $5 \mathrm{mM}$ $\mathrm{KNO}_{3}$. All observations are means of 3 replicates

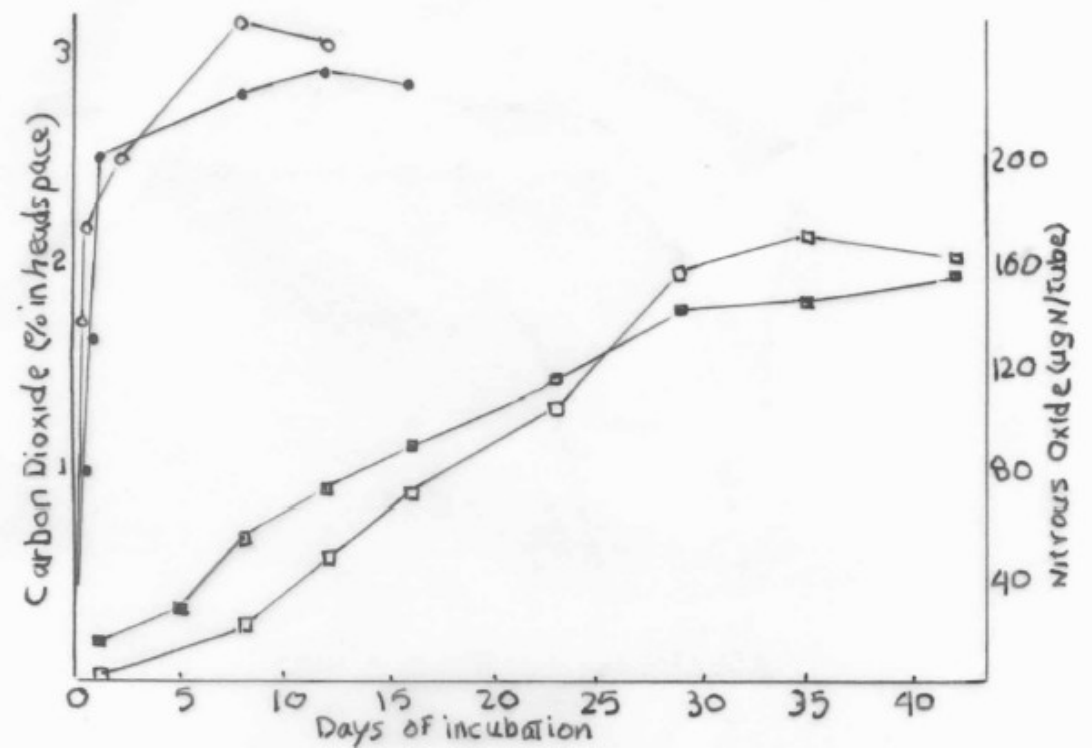

Fig. 2. Long-term production of N2O (Squares) and CO2 (circles) by Bacillus Sp. B37 (solid symbols) and Citrobacter sp. C48 (open symbols) in anaerobic nutrient broth initially conraining 5 mM KNO3. All observations are means of 3 replicates 


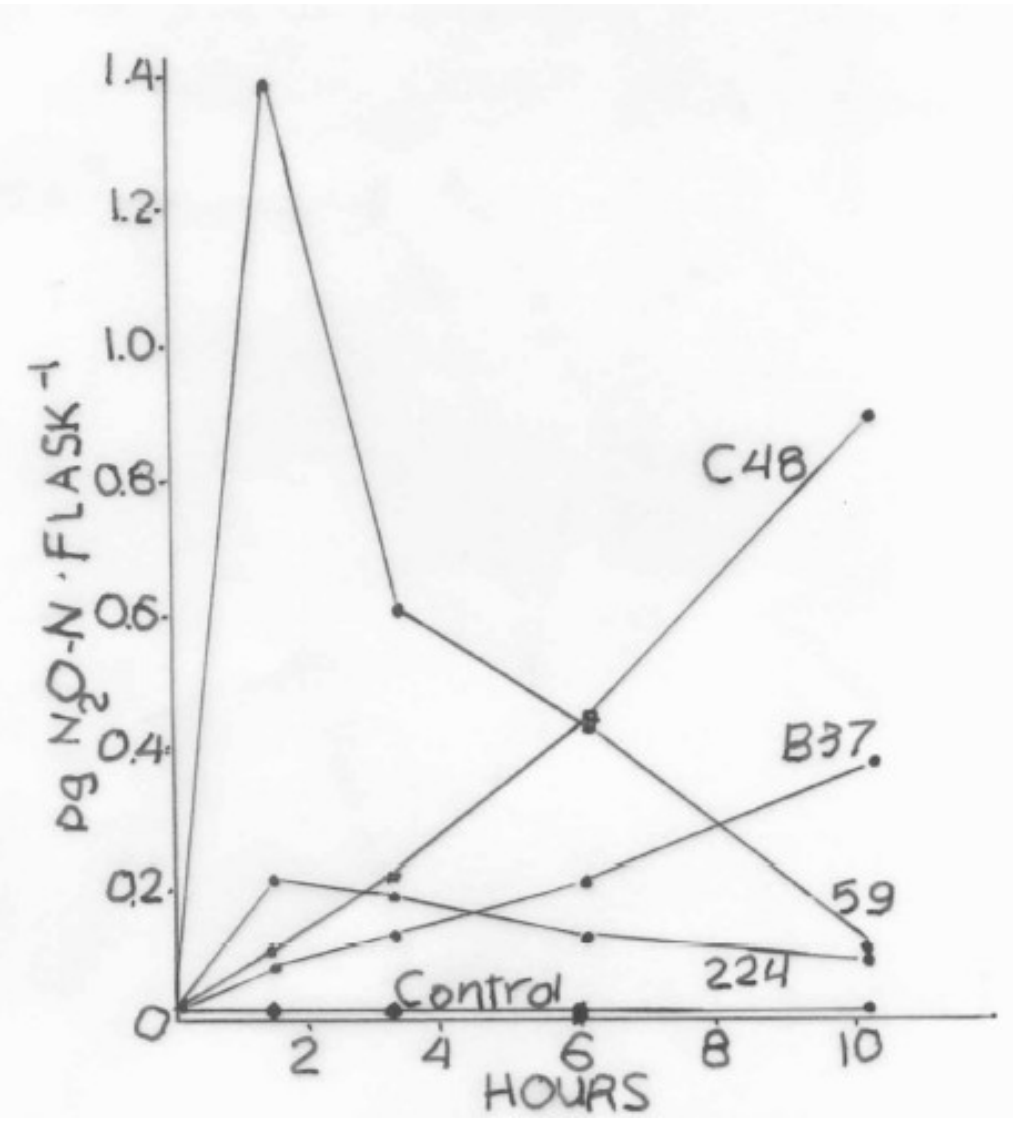

Fig. 3.N2O production by two denitrifiers (59 and 224) and Two Fermentative NO3- reducers (C48 and 837$)$ following addition of cells to anaerobic soil slurries. All observations are means of 3 replicates. All comparisons at a given Time are significantly different at the 0.95 level except 59 vs. C48 at 6 hours and 59 vs.224 at 10 hours

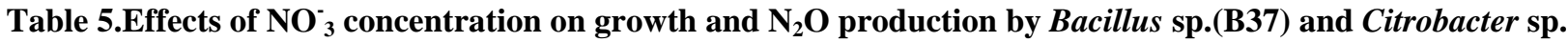
(C48) +

\begin{tabular}{|c|c|c|c|c|}
\hline Isolate & $\mathrm{NO}_{3}^{-}$added $(\mathrm{m} M)$ & $\begin{array}{l}\text { Maximum cell } \\
\text { density (abs.) }\end{array}$ & $\begin{array}{c}\mathrm{N}_{2} \mathrm{O} \text { produced (ug } \\
\mathrm{N})\end{array}$ & $\begin{array}{c}\mathrm{N}_{2} \mathrm{O}-\mathrm{N} \text { as\% of } \mathrm{NO}_{3}^{-}-\mathrm{N} \\
\text { added }\end{array}$ \\
\hline \multirow[t]{5}{*}{ B 37} & 0 & 0.06 & 0 & - \\
\hline & 2 & 0.12 & 9.2 & 13.1 \\
\hline & 6 & 0.18 & 15.3 & 4.4 \\
\hline & 16 & 0.29 & 43.1 & 4.2 \\
\hline & 46 & 0.32 & 172.7 & 5.6 \\
\hline \multirow[t]{5}{*}{ C 48} & 0 & 0.16 & 0 & - \\
\hline & 2 & 0.20 & 7.9 & 11.2 \\
\hline & 6 & 0.31 & 8.8 & 2.6 \\
\hline & 16 & 0.36 & 11.9 & 1.2 \\
\hline & 46 & 0.35 & 35.8 & 1.2 \\
\hline
\end{tabular}

$+\mathrm{N}_{2} \mathrm{O}$ measured at 8 days. Values are means of three replicates in anaerobic nutrient broth.

Increased $\mathrm{N}_{2} \mathrm{O}$ production with increased $\mathrm{NO}_{3}^{-}$was observed upto the highest concentration tested. The percentage of $\mathrm{NO}_{3}^{-}-\mathrm{N}$ converted to $\mathrm{N}_{2} \mathrm{O}$, however, generally decreased with increasing $\mathrm{NO}_{3}^{-}$ concentrations (EL-Sayed and Ahmad, 2003 ).
Table (6) illustrates $\mathrm{N}_{2} \mathrm{O}$ production at various $\mathrm{pH}$ values. Neither organism grew at $\mathrm{pH} 4.0$, and there was no significant accumulation of $\mathrm{N}_{2} \mathrm{O}$ in these tubes. Both organisms produced $\mathrm{N}_{2} \mathrm{O}$ between $\mathrm{pH} 5.0$ and 8.0, and 
both accumulated maximum amounts at $\mathrm{pH} 8.0$, the highest value tested.

In an attempt to elucidate the physiological function of $\mathrm{N}_{2} \mathrm{O}$ production, the observation of growth yields with and without added $\mathrm{NO}_{3}^{-}$or $\mathrm{NO}_{2}^{-}$are shown in Table( 7).The results are confounded by $\mathrm{NO}_{2}^{-}$toxicity which was observed in all cases at $10 \mathrm{~m} \mathrm{M}$. The greatest growth response occurred with $\mathrm{NO}_{3}^{-}$addition, presumably due to respiratory reduction to $\mathrm{NO}_{2}^{-}$. No growth response to added $\mathrm{NO}_{2}^{-}$increased cell yield. Using the data in both Tables (7 and 4) TSB in Table( 7 ) is chemically equivalent to TSBND plus $2.5 \mathrm{~g}^{\text {. }}$ liter $^{-1}$ glucose in Table( 4); and NB in Table (7) is equivalent to unamended NB in (Table 4), the following observations are: (i) in TSB, growth responses to $\mathrm{NO}_{2}^{-}$ occur, $\mathrm{NO}_{2}^{-}$is reduced mostly to $\mathrm{NH}_{4}^{+}$, and small amounts of $\mathrm{NO}_{2}^{-}$are reduced to $\mathrm{N}_{2} \mathrm{O}$; (ii) in $\mathrm{NB}$, there were no growth responses to $\mathrm{NO}_{2}^{-}$, little of the $\mathrm{NO}_{2}^{-}$is reduced to $\mathrm{NH}_{4}^{+}$and small- to- moderate amounts are reduced to $\mathrm{N}_{2} \mathrm{O}$ ( EL-Sayed and Abo-EL-Wafa , 2001). The results are not conclusive but it appears likely that the observed growth responses to $\mathrm{NO}_{2}^{-}$are associated with reduction to $\mathrm{NH}_{4}^{+}$and not to $\mathrm{N}_{2} \mathrm{O}$ (EL-Sayed,2013 ; EL-Soury et al,2015).

Figure (1) illustrates the temporal relationships among growth, $\mathrm{NO}_{3}^{-}$reduction, and $\mathrm{N}_{2} \mathrm{O}$ production for B37 and C48 in NB. Nitrate is essentially reduced completely to $\mathrm{NO}_{2}^{-}(90 \%$ recovery for $\mathrm{B} 37,96 \%$ for C48) at which time growth, as indicated by optical density, ceases. Only at this time does significant $\mathrm{N}_{2} \mathrm{O}$ production occur.

Table 6. Effect of $\mathrm{pH}$ on $\mathrm{N}_{2} \mathrm{O}$ production by Citrobacter sp. $\mathrm{C} 48$ and Bacillus sp. B37.+

\begin{tabular}{ccccc}
\hline Isolate & $\mathbf{p H}$ & \multicolumn{3}{c}{${\text { Percent } \mathbf{N O}_{\mathbf{3}}^{-} \text {-N converted to } \mathbf{N}_{\mathbf{2}} \mathbf{O}}^{\text {Day } \mathbf{1 5}}$} \\
\cline { 3 - 5 } & & Day $\mathbf{2}$ & 0 \\
B37 & 7.0 & 0 & 0 & 0.09 \\
C48 & 7.0 & 0 & 0 & 0.91 \\
B37 & 7.1 & 0.6 & 0.9 & 6.7 \\
C48 & 7.1 & 6.9 & 7.3 & 5.5 \\
B37 & 7.3 & 3.6 & 5.1 & 2.5 \\
C48 & 7.3 & 2.0 & 2.4 & 16.3 \\
B37 & 7.5 & 7.2 & 9.9 & 9.1 \\
C48 & 7.5 & 2.9 & 6.7 & 34.5 \\
B37 & 8.1 & 17.0 & 32.1 & 20.8 \\
C48 & 8.1 & 4.1 & 12.5 & 2.5 \\
\hline
\end{tabular}

+ In nutrient broth with $5 \mathrm{mM} \mathrm{KNO}_{3}$, anaerobic incubation. All observations are means of three replicates.

Table 7. Growth response of Bacillus sp. (B37) and Citrobacter sp. (C48) to added $\mathrm{KNO}_{3}$ or $\mathrm{Na} \mathrm{NO}_{2}$ $\mathrm{N}$ amendment $\quad$ Cell yield in NB\# (ug cell dry wt. $\mathrm{ml}^{-1}$ ) Cell yield in TSB\# (ug cell dry wt. $\mathrm{ml}^{-1}$ )

$(+)$

\begin{tabular}{|c|c|c|c|c|}
\hline & \\
\hline & $\mathrm{C} 48$ & B37 & $\mathrm{C} 48$ & B37 \\
\hline None & 77 & 73 & 514 & 474 \\
\hline $1 \mathrm{~m} M \mathrm{NO}_{2}^{-}$ & 82 & 73 & 521 & 501 \\
\hline $5 \mathrm{~m} M \mathrm{NO}_{2}^{-}$ & $65 \#$ & 70 & $577 \#$ & $628 \#$ \\
\hline $10 \mathrm{~m} M \mathrm{NO}_{2}^{-}$ & $45 \#$ & 49\# & 497 & 271\# \\
\hline $5 \mathrm{~m} M \mathrm{NO}_{3}^{-}$ & 176\# & $162 \#$ & $698 \#$ & $698 \#$ \\
\hline
\end{tabular}

+ Cells harvested in distilled $\mathrm{H}_{2} \mathrm{O}$ at early stationary phase when maximum optical density was attained, weight determined gravimetrically after drying at $85^{\circ} \mathrm{c}$.

++ NB is nutrient broth; TSB is tryptic soy broth with dextrose.

\#Significantly different from broth with no $\mathrm{NO}_{3}^{-}$or $\mathrm{NO}_{2}^{-}$at 0.95 level by two-tailed T- test. Values are means of three replicates.

Table8.Production of $\mathrm{N}_{2} \mathrm{O}$ by resting cell suspensions

Treatment

$\mathrm{N}_{2} \mathrm{O}$ production $\mathrm{P}$ g N $\mathrm{N}_{2} \mathrm{O}-\mathrm{N} .\left(\mathrm{min}^{-1}\right)$

\begin{tabular}{llll}
\cline { 2 - 4 } & & Citrobacter sp. & Bacillus sp. \\
\hline No cells & 0 & 0 & \\
Boiled cells & 0 & 0 & \\
Aerobic atmosphere & 87 & 0 & \\
Glucose omitted & 356 & 50 & \\
Complete anaerobic reaction mixture+ +1153 & 386 & \\
\hline
\end{tabular}

+ Reaction mixture consists of $50 \mathrm{~m} M \mathrm{pH} 7.1$ phosphate buffer, 200 ug*ml $^{-1}$ chloramphenicol, $5 \mathrm{~m} M \mathrm{Na} \mathrm{NO}_{2}, 2.8 \mathrm{~m} M$ glucose, washed, late log phase cells, and $\mathrm{N}_{2}$ atmosphere in $10 \mathrm{ml} \mathrm{H}$. Values are means of two replicates. 
Figure(2) presents a surprising aspect of $\mathrm{N}_{2} \mathrm{O}$ production by these organisms. Nitrous oxide production occurs at a more or less linear rate for up to 35 days, long after growth steps(EL-Sayed, 2003 (a\&b)). Most of the $\mathrm{CO}_{2}$ in the headspace of these tubes accumulated within 24 hours, and no significant increases were observed after 8 days. The results suggest that $\mathrm{N}_{2} \mathrm{O}$ production is not directly associated with growth of the organism ( Fathi ,2014).

These results indicate that $\mathrm{N}_{2} \mathrm{O}$ production by these organisms is a biological and not a chemical process. In one experiment, $\mathrm{Hg} \mathrm{Cl}_{2}$ was added to early stationary phase cultures which had accumulated $\mathrm{NO}_{2}^{-}$and were producing $\mathrm{N}_{2} \mathrm{O}$. This abolished $\mathrm{N}_{2} \mathrm{O}$ production; distilled $\mathrm{H}_{2} \mathrm{O}$ did not. Further evidence of enzymatic involvement ; in $\mathrm{N}_{2} \mathrm{O}$ production was provided by resting cell suspensions prepared from washed, early stationary phase cells (Table 8). Boiling cells for $5 \mathrm{~min}$ abolished activity. These experiments also show that $\mathrm{O}_{2}$ is an effective inhibitor of $\mathrm{NO}_{2}^{-}$reduction to $\mathrm{N}_{2} \mathrm{O}$. Furthermore, it was observed that glucose caused a several- fold increase in $\mathrm{N}_{2} \mathrm{O}$ production. Boiled and live $\mathrm{C} 48$ cells from a 28-day-old culture were also assayed with results consistent with those in Table (8).

An additional resting cell experiment was performed to determine the effect of growth conditions on $\mathrm{N}_{2} \mathrm{O}$ producing activity from $\mathrm{NO}_{2}^{-}$, Citrobacter $\mathrm{C} 48$ was grown in TSB aerobically with no $\mathrm{NO}_{3}^{-}$or $\mathrm{NO}_{2}^{-}$, anaerobically with neither $\mathrm{NO}_{3}^{-}$nor $\mathrm{NO}_{2}^{-}$, and anaerobically with $5 \mathrm{~m} M \quad \mathrm{KNO}_{3}$ (EL-Sayed, 2005 ). The relative activities were $1.4,7.5$, and 100, respectively. It appears that $\mathrm{N}_{2} \mathrm{O}$ producing activity is inducible.

\section{$\mathrm{N}_{2} \mathrm{O}$ Production by Fermentative $\mathrm{NO}_{2}^{-}$Reducers in Soil}

The results presented in Fig (3) showed that these organisms produce immediately $\mathrm{N}_{2} \mathrm{O}$ when added to anaerobic autoclaved soils. Two denitrifying pseudomonads (isolates 59 and 224) were included in this experiment for purposes of comparison. The denitrifiers initially produced $\mathrm{N}_{2} \mathrm{O}$ at a greater rate than the fermentative $\mathrm{NO}_{2}^{-}$reducers, but $\mathrm{N}_{2} \mathrm{O}$ did not accumulate in the soils with denitrifiers due to reduction to $\mathrm{N}_{2}$. After 10 hours of incubation, $\mathrm{C} 48$ and B37 had accumulated significantly more $\mathrm{N}_{2} \mathrm{O}$ than the denitrifiers (EL-Sayed, 1999 and 2016).

\section{CONCLUSIONS}

Most soil isolates capable of dissimilatory $\mathrm{NO}_{3}^{-}$ reduction to $\mathrm{NO}_{2}^{-}$also produced $\mathrm{N}_{2} \mathrm{O}$, though most of these isolates were not true respiratory denitrifiers. Nitrous oxide production by nondenitrifiers differed from denitrification in several ways. Ionic forms of nitrogen $\left(\mathrm{NH}_{4}^{+}\right.$or $\left.\mathrm{NO}_{2}^{-}\right)$were the predominant products in the former process, with lesser amounts of $\mathrm{N}_{2} \mathrm{O}$, whereas denitrifiers have the potential for complete conversion of $\mathrm{NO}_{3}^{-}$sto nitrogen gas. The bacteria characterized in this study apparently cannot reduce $\mathrm{N}_{2} \mathrm{O}$ to $\mathrm{N}_{2}$, but most denitrifiers can.Production of $\mathrm{N}_{2} \mathrm{O}$ by denitrifiers is directly linked to growth and respiration and so is a relatively rapid process when conditions are favorable.Production of $\mathrm{N}_{2} \mathrm{O}$ by nondenitrifiers is slower and occurs mostly after apparent growth is completed.

The results suggest that $\mathrm{N}_{2} \mathrm{O}$ production by nondenitrifying $\mathrm{NO}_{3}^{-}$reducers is enzymatic, though the involvement of a nonenzymatic step cannot be definitely ruled out. Boiling cells and treatment with $\mathrm{HgCl}_{2}$ abolished activity. Nitrous oxide producing activity apparently was induced by anaerobic growth with $\mathrm{NO}_{3}^{-}$. Activity was favored by high $\mathrm{pH}$, suggesting that $\mathrm{N}_{2} \mathrm{O}$ production is not due to chemical decomposition of $\mathrm{HNO}_{2}$. The physiological function, if any exists, of $\mathrm{N}_{2} \mathrm{O}$ production by these organisms is not clear. The results do not indicate that this process is directly linked to growth or energy generation, as is the case for respiratory denitrification and for fermentative reduction of $\mathrm{NO}_{2}^{-}$to $\mathrm{NH}_{4}^{+}$. IF $\mathrm{N}_{2} \mathrm{O}$ production serves as a means of detoxifying $\mathrm{NO}_{2}^{-}$, it is a rather inefficient mechanism since $\mathrm{NO}_{2}^{-}$conversion is slow and incomplete. Since added $\mathrm{NH}_{4}^{+}$did not inhibit $\mathrm{N}_{2} \mathrm{O}$ production; $\mathrm{NO}_{2}^{-}$reduction to $\mathrm{N}_{2} \mathrm{O}$ is not associated with assimilatory $\mathrm{NO}_{2}^{-}$reduction.

The supply of energy substrate had variable effects on $\mathrm{N}_{2} \mathrm{O}$ production. Glucose addition enhanced $\mathrm{N}_{2} \mathrm{O}$ production in resting cell suspensions, but in Batch cultures it sometimes increased and sometimes decreased evolution of $\mathrm{N}_{2} \mathrm{O}$. Growth in TSB often resulted in less $\mathrm{N}_{2} \mathrm{O}$ release than in nutrient broth, but in a few cases; more $\mathrm{N}_{2} \mathrm{O}$ was produced in TSB. No facile explanation for these varying effects is at hand.

Most of the nondenitrifying $\mathrm{N}_{2} \mathrm{O}$ producers were apparently capable of fermentative dissimilatory reduction of $\mathrm{NO}_{2}^{-}$to $\mathrm{NH}_{4}^{+}$under the appropriate conditions. The Bacillus and Citrobacter isolates were $\mathrm{NO}_{2}^{-}$accumulators in $\mathrm{NB}$, in TSB they were $\mathrm{NH}_{4}^{+}$ producers. This was also true for 48 of 58 soil isolates which were initially classified as $\mathrm{NO}_{2}^{-}$accumulators in NB .This suggests that, for many bacteria, reduction beyond the initial $\mathrm{NO}_{3}^{-}$to $\mathrm{NO}_{2}^{-}$step is limited more by the environment than by the genetic potential of the organisms. In any case, more ionic $\mathrm{N}$ was produced than gaseous $\mathrm{N}$, so fermentative $\mathrm{NO}_{3}^{-}$reducers might be less likely than denitrifiers to cause significant volatile 
loss of fixed soil $\mathrm{N}$. If $\mathrm{NO}_{2}^{-}$reduction to $\mathrm{NH}_{4}^{+}$were competitive with denitrification, gaseous $\mathrm{N}$ loss could actually by reduced by these organism.

It is difficult to evaluate the significance of nondenitrifying $\mathrm{NO}_{3}^{-}$reducers as a source of soil $\mathrm{N}_{2} \mathrm{O}$. These organisms did produce $\mathrm{N}_{2} \mathrm{O}$ under a wide variety of conditions. From the survey it appears that they are more numerous than denitrifiers in soil. When added to autoclaved soil, fermentative $\mathrm{NO}_{2}^{-}$reducers initially produced $\mathrm{N}_{2} \mathrm{O}$ at a lower rate than denitrifiers but, because they also consumed $\mathrm{N}_{2} \mathrm{O}$,denitrifiers accumulated less $\mathrm{N}_{2} \mathrm{O}$ as the incubation proceeded. Nondenitrifying $\mathrm{NO}_{3}^{-}$reducers may thus contribute to $\mathrm{N}_{2} \mathrm{O}$ evolution from soil .

\section{ACKNOWLEDGMENTS}

The author wish to acknowledge grateful and special thanks to the irrigation Eng.Mohammed Said Abbas Mohammed EL-Sayed and his wife irrigation Eng.Mariam Ehab Ibraheem for valuable practically supported to this research for providing inoculum.

\section{REFERENCES}

Abdel-Aziz , N.A.M ; M.A. Abdel-Samad and S.A.M. ELSayed .2003 . Relationship between soil texture , mineralization rate of nitrogen, carbon and microorganioms in soil . J . Agric . Sci . Mansoura Univ . 28 (4) : 3275 - 3298.

Breitenbeck, G.A.;A.M.Blackmer, and J.M. Bremner. 1980. Effects of different nitrogen fertilizers on emission of nitrous oxide from soil. Geo- phys. Res. Lett. 7:85-88.

Bremner, J.M., and A.M. Blackmer. 1978. Nitrous oxide emission from soils during nitrification of fertilizer nitrogen. Science. 199:295-296.

Caskey, W.H., and J.M. Tiedje. 1979. Evidence for clostridia as agents of dissimilatory reduction of nitrate to ammonium in soils. Soil Sci. Soc. Am. J.43:931-936.

Christopher , F ; D , Ryan ; E. Marie and G.Carcia - Cabellos . 2017 . Developing microbial inocula to support biofuel crop cultivation on tributyltin contaminated marine sediments . Journal of Applied \& Environmental Microbiology. 5 (2) : 47-56.

Cole, J.A., and C.M. Brown. 1980. Nitrite reduction to ammonia by fermentative bacteria: a short circuit in the biological nitrogen cycle. FEMS Microbial. Lett. 7:65-72.

Council for Agricultural Science and Technology (C. A. S. T.). 1976. Effect of increased nitrogen fixation on stratospheric ozone. Report no. 53. Iowa State University. Ames.

Crutzen, P. J., and D. Ehhalt. 1977. Effects of nitrogen fertilizer and combustion on the stratospheric ozone layer Ambio. 6: 112-117.

EL-Sayed , S.A.M . 1995a . Manure decomposition during arobic and anaerobic condition. Menofiya . J . Agric . Res . 20 (2) : $777-788$.
EL-Sayed , S.A.M. 1995 b. Identification of rhizobacteria from forage sorghum and apppraise their plant growth promoting activity . J . Agric .Sci . Mansoura Univ . 20 (1) : $441-451$.

EL-Sayed , S.A.M. 1999 . Denitrification by guar rhizobia strains in New Valley Governorate. Egypt . J . Soil Sci . 39 (2) : $223-236$.

EL-Sayed , S.A.M . 2002 a. Effectiveness of some nitrification inhibitors in soil amended with sewage sludge compost . Int . Conf . for Develop. and The Env. In the Arab world , March , 26-28, 2002 . Assiut Univ. Center for Environ Studies . Egypt . pages from 223 to 236.

EL-Sayed, S.A.M 2002b. Relationship between ammonium thiosulfate (ATS) and inhibition of nitrification or urea hydrolysis in soil . Alex . Sci . Exch . 23 (3) : $243-254$.

EL-Sayed, S.A.M . 2003 a. The effect of soil temperature on denitrification and ammonification . Egypt . J . Soil Sci . 43 (4) : $447-465$.

EL-Sayed , S.A.M. 2003b . Nitrogen immobilization and mineralization as affected by fertilizer application in soils . Egypt . J . Soil Sci . 43 (4) : 467- 480.

EL-Sayed, S.A.M. 2004 . Relationship between nitrification inhibitors and many of acetylenic compounds in soils . J . Agric . Sci . Mansoura Univ ; 29 (3) : 1527 - 1538.

EL-Sayed, S.A.M . 2005 . Relationship between soil amended with manure and emissions of nitrogen oxides . Alex . Sci . Exch. Jour. 26 (3): $199-210$.

EL-Sayed , S.A.M . 2013 . A stimulating effect of humic compounds on the growth of legumes, nodulation and biological nitrogen fixation . Alex . Sci . Exch . Jour . 34 (4) : $387-394$.

EL-Sayed , S.A.M. 2016 . Survey of Vesiculare - Arbuscular Mycorrhizal Fungi in the Faculty of Agriculture Farm , Al-Azhar University, Assiut Governorate. Alex . Sci . Exch . Joul . 37 (3) : 507 - 514.

EL-Sayed, S.A.M;A.S.A, Abdel-Mawgoud ; S.A.M . Hegab and M.H.E , Salem .2001. Soil salinity and nitrification inhibitors in barley plant . Egypt . J . Soil Sci . 41 (4) : 539 -550 .

EL-Sayed, S.A.M. and A.M. , Abo-EL-Wafa .2001 . Effects of biofertilizers on nitrogen fixation, nitrogen uptake and yield of wheat . J . Agric . Sci . Mansoura Univ , 26 (7) : $4583-4592$.

EL-Sayed , S.A.M and M.E. Ahmad.2003. Effect of water shortage and potassium on efficiency of symbiotic nitrogen fixation in some legumes. Egypt J . Soil Sci . 43 (2) : $193-210$.

EL-Soury , A.H; A.E .Shouman ; S.A.E. Abdelrazek and H.M.EL-Komy.2015.Microbial biomass and activity in a calcareous soil amended with municipal solid waste compost . Alex . Sci . Exch . Jour . 36 (3) : 262-266.

Fathi , N.O.2014. Crop yield and nitrogen bioavailability mediated by nitrogen fertilization in maize \ soybean intercropping system with and without rhizobium inoculation . Alex . Sci . Exch . Jour . 35 (2) : $115-125$. 
Faith , B ; S.L ,Jacquelyn ;H.J.S.L., Norma .2017 . Fresh produce microbial indicator contamination farms and packing facilities : elucidation of environmental routes. Applied and Environmental Microbiology (article) .

Gamble. T. N., M. R. Betlach, and J. M. Tiedje. 1977. Numerically dominant denitrifying bacteria from world soils. Appl. Environ. Microbial. 33:926-939.

Khalafalla , M.y and M.H. Hamed . 2015 . Impact of nitrogen fertilization on soil organic carbon decomposition. Alex . Sci . Exch . Jour . 36 (4) : 381-389

Lowe, R. H., and J. L. Hamilton. 1967. Rapid method for determination of nitrate in plant and soil extracts. J. Agric. Food Chem. 15:359-361.

Mc Elroy, M. B., S. C. Wolfsy, and Y. L. Yung. 1977. The nitrogen cycle: Perturbations due to man and their impact on atmospheric $\mathrm{N}_{2} \mathrm{O}$ and $\mathrm{O}_{3}$. Philos. Trans. R. Soc. London. 277B:159-181.

Nelson, D. W., and J. M. Bremner. 1970. Gaseous products of nitrite decomposition in soils. Soil Biol. Biochem. 2: 203215.

Payne, W. J. 1973. Reduction of nitrogenous oxides by microorganisms. Bacterial. Rev. 37: 409-452.

Rajesh,M; M.Samundesswari and B.Archana . 2017 . Isolation of biosurfactant producing bacteria from garbage soil . Journal of Applied \& Environmental Microbiology . 5 (2) : 74-78.

Sorenson, J. 1978. Capacity for denitrification and reduction of nitrate to ammonia in a costal marine sediment. Appl. Environ. Microbiol. 35: 301-305.

Yoshida, T., and M. Alexander. 1970. Nitrous oxide formation by Nitro- somas europaea and heterotrophic microorganism. Soil Sci. Soc. Am. Proc. 34: 880-882.

\title{
الملخص العربي
}

\section{حصر للبكتيريا الموجودة بمزرعة كلية الزراعة - جامعة الأزهر بمحافظة أسيوط}

\author{
سعيد عباس محمد السيد
}

نقية، كذلك عند وضع التربة فى جهاز التعقيم (الاتوكلاف)

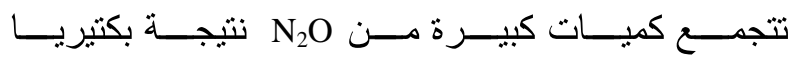
Pseudomonads

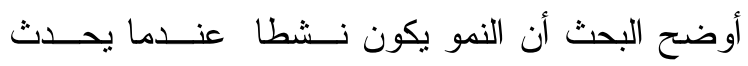

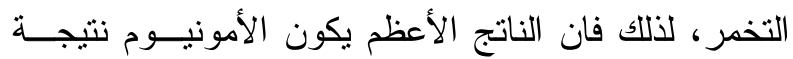

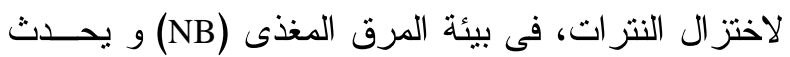

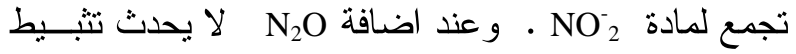

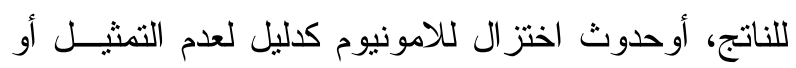

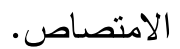

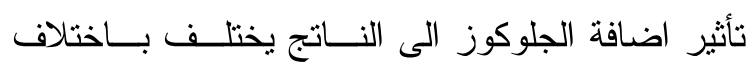
الكائنات الحية الدقيقة فى الوسط البيئى، اكــسيد النيتــروز

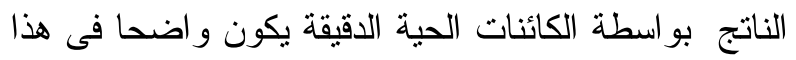
التفاعل الحيوى .و ينتج

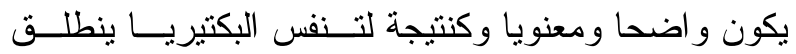

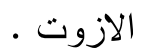

تم عزل 10 ب من البكتريا القادرة على اختز ال النترات ( و كذلك • (Y من البكتيريا المنتجة لأكسيد النيتروز ( $\left.\mathrm{N}_{2} \mathrm{O}\right)$ لاختز ال النترات الى غاز النيتروجين .

أوضحت النتائج أن النتريت أو الامنيــوم كــان النــاتج

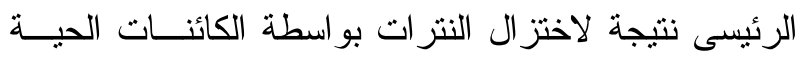
الدقيقة نتيجة لبكتيريا عكس النأزت .

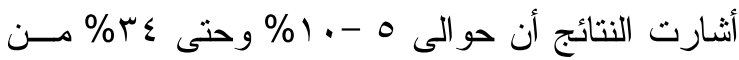

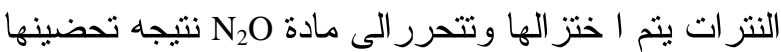

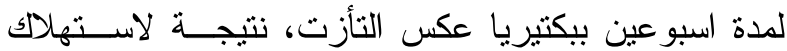

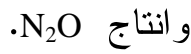

أوضـــت النتــائج أن بكتيريــا Bacillus و بكتيريــا Enterobacter عكس التأزت و التى تتنج مادة N

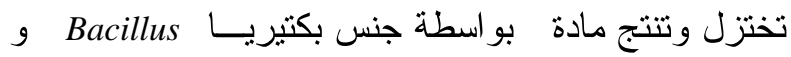
كذللك جنس Citrobacter تكون مميزة لانتاج مـز بـارع 